NBER WORKING PAPER SERIES

\title{
VIOLATING THE LAW OF ONE PRICE: SHOULD WE MAKE A FEDERAL CASE OUT OF IT?
}

\author{
Charles Engel \\ John H. Rogers
}

Working Paper 7242

http://www.nber.org/papers/w7242

\author{
NATIONAL BUREAU OF ECONOMIC RESEARCH \\ 1050 Massachusetts Avenue \\ Cambridge, MA 02138 \\ July 1999
}

We thank Dwight Bibbs, Gabriele Galati, Sharon Gibson and Dave Wilcox for assistance with the data, and Asim Husain for outstanding research assistance. Engel acknowledges assistance from a grant by the National Science Foundation to the National Bureau of Economic Research. The views expressed in this paper are those of the authors and do not necessarily reflect those of the Board of Governors of the Federal Reserve, the Federal Reserve System, or the National Bureau of Economic Research. 
(C) 1999 by Charles Engel and John H. Rogers. All rights reserved. Short sections of text, not to exceed two paragraphs, may be quoted without explicit permission provided that full credit, including $\odot$ notice, is given to the source.

Violating the Law of One Price:

Should We Make A Federal Case Out of It?

Charles Engel and John H. Rogers

NBER Working Paper No. 7242

July 1999

JEL No. E3, E4

\section{ABSTRACT}

We use new disaggregated data on consumer prices to determine why there is variability in prices of similar goods across U.S. cities. We address questions similar to those that have arisen in the international context: is this variability purely a result of market segmentation or do sticky nominal prices play a role? We also examine how the degree of tradability of a good influences price variability. Surprisingly, we find that variability is larger for traded-goods. We attribute this finding to greater price stickiness for nontraded goods. Distance between cities accounts for a significant amount of the variation in prices between pairs of cities. But we also find that nominal price stickiness plays an even more significant role.

Charles Engel

Department of Economics

University of Washington

Seattle, WA 98195

and NBER

cmengel@u.washington.edu
John H. Rogers

Board of Governors of the

Federal Reserve System

Washington, DC 20551

rogersj3@frb.org 
Recent empirical work in international economics has focused on the segmentation of markets. It has become increasingly clear that markets are far from being perfectly integrated across countries, although the ultimate cause of this lack of integration remains to be completely understood. A new strand in the literature has noted that the underlying premise of theories of market segmentation might apply to markets within countries as well as markets across countries. If transportation costs explain why markets are not fully integrated, then we ought to find similar determinants of the patterns of trade and prices intranationally as we do internationally.

A number of studies have compared patterns of trade or prices within Canada and the U.S. versus across the border. McCallum (1995) and Helliwell (1996) examine trade volumes and find a large border effect - a state and a province that lie directly across the U.S./Canadian border have much less trade than would be predicted by their relative sizes and the physical distance between them. Engel and Rogers (1996) find a large border effect in prices. Distance explains some of the variability of prices of similar goods across U.S. and Canadian cities, but by itself cannot explain the degree of segmentation between locations across the border.

In this study, we use new disaggregated data on consumer prices to explain the variability in prices of similar goods across U.S. cities. We address questions similar to those that have arisen in the international context: is this variability purely a result of market segmentation or do sticky nominal prices play a role?

The version of the law of one price that we test might be called the "proportional law of one price" (PLOP) because our data is in the form of price indexes. In particular, we measure the standard deviation of changes in the log of the relative price (index) of good $\mathrm{j}$ across locations $\mathrm{k}$ and $\mathrm{m}$, $\Delta p_{j t}^{k}-\Delta p_{j t}^{m}$. A finding that this measure of price variability is low indicates that percentage changes in the price of $\operatorname{good} j$ in location $k$ relative to location $m$ are small. Numerically this could occur because 
(1) the "absolute law of one price holds", so that the difference in the price of good $j$ itself in locations $k$ and $m$ is close to zero; (2) the price in one location $k$ is roughly proportional to the price in location $m$, so $p_{j t}^{k}-p_{j t}^{m}$ is nearly constant; or, (3) because $\Delta p_{j t}^{k}$ and $\Delta p_{j t}^{m}$ are nearly constant. Were we to use price levels rather than price indexes, we would be able to distinguish between these three possibilities.

In section 2, we replicate Engel's (1993) international study with our data from U.S. cities. Using data at the national level, Engel compared the prices of similar goods across countries to the relative price of different goods within a country, and found the former to be much more variable in general. We ask whether the same is true for U.S. city prices. Engel contends that nominal price stickiness might be one explanation for his results. In each country, prices are sticky in the consumers' currencies, but the nominal exchange rate is not sticky, so as it varies the common currency prices of the goods vary. However, for our data on prices for cities in the U.S., there is no nominal exchange rate variability. So, if we find deviations within the U.S. that are of similar magnitude to what Engel (1993) finds, we might conclude that sticky prices cannot be the explanation for his finding.

The comprehensiveness of our data also allows us to examine how the degree of tradability of a good influences deviations from the PLOP. We expect deviations to be smaller for the goods that have a smaller non-traded component (see, e.g., Kravis and Lipsey (1988)). Section 3 provides some evidence on this issue. Surprisingly, we find deviations are larger for traded-goods. We attribute this finding to greater price stickiness for non-traded goods.

In section 3, we also explore other reasons for the failure of the PLOP: specifically, that markets that are more segmented by distance will have greater deviations. Distance between cities does account for a significant amount of the variation in prices between pairs of cities. But we find that nominal price stickiness plays a more significant role in the behavior of U.S. prices. 


\section{The Data}

The data are monthly for 29 U.S. cities, starting in December 1986 and ending June 1996. For each city, we have price indexes for 43 different goods (and the overall C.P.I. for the city.) Table 1 lists the cities and the goods. There is a fair amount of disaggregation. Aside from homeowners' costs, which represent an expenditure share of $19.825 \%$ for the average consumer ${ }^{1}$, the largest category, food away from home, has only a $6.189 \%$ share. Most of the category shares are much smaller. Altogether, these goods comprise over $99 \%$ of consumption expenditures. ${ }^{2}$

Parsley and Wei (1996) also use data on consumer prices in U.S. cities to test hypotheses concerning the law of one price. They use actual goods prices rather than price indexes, and so examine deviations from the ("absolute") law of one price. They find that convergence to the law of one price among cities within the U.S. is significantly faster than the typical estimates of the speed of convergence to purchasing power parity across countries. They conclude that distance alone cannot explain why convergence is faster within the U.S. than it is across countries.

Comparing and contrasting their data set with ours helps motivate the tests we undertake. The Parsley-Wei data is from the American Chamber of Commerce Association, while ours is official data from the Bureau of Labor Statistics. The BLS samples prices from a number of outlets in each city for each good, and undertakes considerable effort to insure comparability of products and outlets across cities. The sampling methodology of the Chamber of Commerce appears not to be as rigorous.

Our data comprises prices on nearly 100 per cent of consumer expenditures. Their data covers prices of goods and services comprising a much smaller portion of expenditures. Our data is generally not as disaggregated as theirs. The data used by Parsley and Wei is for 51 very specific and homogenous goods and services such as bacon, margarine, bowling and men's haircuts. Our data is from the 29 largest U.S. cities that span the U.S. geographically. Parsley and Wei's data is for 48 cities 
of varying size, without quite as much geographical dispersion. Our time series is for ten years, while most of their series are seventeen years. There is no missing data in our time series, while their series have occasional missing observations.

Parsley and Wei focus on the time-series properties of their prices. They investigate whether deviations from the law of one price are stationary. They generally reject unit roots, and then ask what economic factors affect the speed of convergence. While the distance between locations tends to make the adjustment take longer, they find that the distance effect is relatively small. ${ }^{3}$

As we noted above, data on actual price levels would allow us to measure absolute deviations from the law of one price. Principally, we do not take that tack because of the quality of price-level data that is available. In our data, deviations from PLOP might be small, but absolute deviations from the law of one price could be large and undetected. Factors such as transportation costs and marketing costs could drive a wedge between price levels in two cities, but if those factors remain fairly constant over time, then PLOP deviations will be small. We cannot lay claim to a comprehensive investigation of why prices differ across locations. But we shall see that the investigation of the causes for PLOP deviations is revealing of the price-setting process.

\section{How Important are Failures of the Law of One Price?}

There can be little doubt about the importance of national borders to the integration of markets. In previous work, we have argued that the deviations from the law of one price across countries are a prime suspect in the failure of purchasing power parity (PPP). Recalling four textbook explanations for PPP not holding: 
(1) Barriers to trade such as tariffs and transportation costs; (2) Different consumption preferences across countries; (3) Presence of non-traded goods in consumer price indexes (CPIs); and (4) Prices that are sticky in terms of the currency in which the good is consumed, note that explanations (1) and (4) depend on deviations from the law of one price across countries, while explanations (2) and (3) imply significant relative price movements within a country.

In this section, we generalize the approach taken in Engel (1993) to examine the relative contributions of these two general explanations for the failure of PPP across U.S. cities. To understand this approach in its simplest form, consider two goods, $i$ and $j$, and two locations, $A$ and $B$. Engel compares $V\left(p_{i}^{A}-p_{j}^{A}\right)$ to $V\left(p_{i}^{A}-p_{i}^{B}\right)$, where $V\left(p_{i}^{A}-p_{j}^{A}\right)$ is the volatility of the price of $\operatorname{good} i$ relative to another good $j$ within the same location, $A$, and $V\left(p_{i}^{A}-p_{i}^{B}\right)$ measures the volatility of the (common-currency) price of the same good, $i$, in location $A$ relative to location $B$. The second and third explanations of PPP failures would contend that $V\left(p_{i}^{A}-p_{j}^{A}\right)$ should exceed $V\left(p_{i}^{A}-p_{i}^{B}\right)$, while the first and fourth explanations predict the reverse.

Engel computes volatility as the variance of the first-differences (or, alternatively, $3^{\text {rd }}, 6^{\text {th }}$, or $12^{\text {th }}$-differences) of the logs of monthly prices. He uses data for the $\mathrm{G} 7$ countries of four price indexes (the overall CPI and CPIs for food, shelter and services) and for consumer prices of 33 narrowly defined categories of goods between the U.S. and Canada. With only a few exceptions, he finds $V\left(p_{i}^{A}-p_{i}^{B}\right)>V\left(p_{i}^{A}-p_{j}^{A}\right)$. Failures of the law of one price appear to be much more pronounced than the intra-country relative price changes that motivate some theories of real exchange rate movements.

We replicate Engel's analysis on our disaggregated consumer prices for U.S. cities. Define $\Delta p_{j, t}^{k}$ to be the first-difference of the $\log$ of the price of $\operatorname{good} j$ at location $k$ at time $t$. For every good, $j$ $=1,2, \ldots, 43$, and every location, $k=1,2, \ldots, 29$ we calculate the ratio $r_{k j}$ : 


$$
r_{k j}=\frac{\frac{1}{42} \sum_{n=1, n \neq j}^{43} s d\left(\Delta p_{j t}^{k}-\Delta p_{n t}^{k}\right)}{\frac{1}{29} \sum_{m=1, m \neq k}^{29} s d\left(\Delta p_{j t}^{k}-\Delta p_{j t}^{m}\right)},
$$

where $s d($.$) refers to standard deviation.$

In words, the numerator of $r_{k j}$ in equation (1) represents the average of the standard deviations of the first difference of the price of good $j$ relative to the price of each different good in location $k$. So, the numerator measures the volatility of a relative price of different goods in the same location. The denominator of $r_{k j}$ in equation (1) is the average standard deviation of the first difference of the price of good $j$ in location $k$ relative to the price of the same good in different locations. So, the denominator measures the volatility of deviations from the law of one price. A small value of $r_{j k}$ means that violations of the law of one price are large by Engel's (1993) measure.

Table 1 reports the average of the $r_{j k}$ ratios from equation (1) across locations for each good. If these ratios were to conform to Engel's (1993) findings, they should generally be very small - much less than one. The average value would need to be around 0.15 to replicate Engel's findings. However, the ratios actually are mostly greater than one (the smallest value is 0.71 ). Since the numerator of our ratio is quite similar to the numerator in Engel's calculations - it is the standard deviation of relative prices of different goods within the U.S. - the larger ratios in this paper result from smaller denominators. Law of one price deviations are not as important for locations within the U.S. as compared to deviations among countries.

The statistics reported in the first column of Table 1 are for the monthly differences in logs of prices. The second column of Table 1 reports analogous statistics for 24-month differences. The surprising thing about this table is that the $r_{j k}$ ratios do not change very much. We would expect the $r_{j k}$ ratios to rise, since the law of one price should hold more nearly over longer time spans. The smaller the law-of-one-price deviations, the smaller should be the denominators of the $r_{j k}$ ratios. Taking a 
weighted average across goods (with the weights equal to the weights each good receives in the C.P.I.), the average $r_{j k}$ is 2.03 for monthly differences, and 1.75 for 24 -month differences. The 24 -month ratios actually are slightly lower, which is the opposite of what one would expect.

As noted above, the version of the law of one price we test is perhaps more accurately called the "proportional law of one price" (PLOP). How do we interpret the finding that PLOP holds more nearly within the U.S. than across national borders? It is consistent with the sticky-price view of the world. If nominal prices are sticky - so that $\Delta p_{j t}^{k}$ and $\Delta p_{j t}^{m}$ have low variances - PLOP would hold for reason (3) above. Note the contrasting implications of sticky prices for PLOP when we examine prices across countries versus prices within a country. For prices of similar goods across countries, commoncurrency relative prices will have a high variance because the nominal exchange rate has a large variance, while domestic-currency goods prices are nearly constant. If we look at locations within a country, the log of the nominal exchange rate is zero. Therefore, the sticky price explanation posits that when the price of good $j$ between locations $k$ and $m$ within countries, $p_{j}^{k}-p_{j}^{m}$, has a low variance, it is because $p_{j}^{k}$ and $p_{j}^{m}$ have low variances.

Alternatively, the finding of small PLOP deviations within the U.S. is consistent with a flexible price world in which the degree of market segmentation for consumer goods depends on barriers to trade such as distance. The distance between U.S. city pairs generally is less than the distance between the country pairs in Engel's (1993) study. It may be that economic agents rapidly take advantage of any price discrepancies between locations within the U.S. and eliminate law-of-one-price deviations, while such arbitrage is more costly across national borders. So, the small deviations from PLOP in the U.S. may genuinely reflect small deviations from price equality across locations.

The finding that the variance of $p_{j}^{k}-p_{j}^{m}$ is small within the U.S. compared to PLOP deviations across national borders could be consistent either with a model in which prices are sticky, or with a 
model in which markets for goods work efficiently and markets are highly integrated within the U.S. In the remainder of the paper, we attempt to find evidence that might support one or the other (or both) theories. Our principal source of evidence, paradoxically, is evidence on what leads to the failure of PLOP within the U.S. While PLOP holds much more nearly intra-nationally than internationally, by no means does PLOP hold perfectly within the U.S.

\section{What Determines Deviations from PLOP?}

If transportation costs are responsible for the large failures of PLOP across national borders, and low transportation costs can explain why PLOP holds more nearly within the U.S., then the within-U.S. failures of PLOP should be greater for goods that are more expensive to transport. PLOP should not hold as well for "non-traded" goods.

We classify each of our 43 goods as either traded or non-traded. The classification is not based on any data on the volume of shipments of the goods. Instead, we follow logic and common sense goods are generally classified as traded and services as non-traded. The goods classified as non-traded are labeled with an ' $\mathrm{N}$ ' in Table 2. In some cases, it is not obvious from the name of the good why we chose its particular classification, because for some categories the name of the good is a misleading indicator for what is included in that category. For example, we classify public transportation as a traded good. This is because intercity air, bus and rail transportation comprise a large portion of this category (intracity bus rides and taxi rides are also included in the public transportation category).

We expect the standard deviation of $\Delta p_{j t}^{k}-\Delta p_{j t}^{m}$ to be larger if $j$ is a non-traded good. The first column in Table 2 reports this standard deviation for each good (averaged across the cities.) The standard deviation for non-traded goods is substantially lower than for traded goods. The weightedaverage value for non-traded goods is 1.74 , while for traded goods it is 4.35 . Examining individual 
goods in Table 2, one finds that most of the goods with the largest deviations from PLOP are traded goods. For example, the ten goods which deviate from PLOP the most are all traded goods - infants' and toddlers' apparel; women's and girls' apparel; fish and seafood; other apparel commodities; eggs; textile housefurnishings; fresh fruits and vegetables; poultry; fuels; and, furniture and bedding. Of the ten goods with the lowest deviations from PLOP, only two - new vehicles, and used cars - are traded goods. The other eight - food away from home; rent, residential; homeowner's costs; professional medical services; personal and educational expenses; housekeeping services; other private transportation; and auto maintenance and repair - are all non-traded goods or services.

One concern arises from using the standard deviations of monthly-differences of relative prices. Suppose that the relative price adjusts rapidly: might this relative price actually exhibit more short-term volatility than a slow-adjusting price because there is a lot of adjustment occurring in the short run? In other words, suppose prices $q=p_{j}^{k}-p_{j}^{m}$ follow an AR(1) process:

$$
q_{t}=a+b \cdot q_{t-1}+u_{t}
$$

where $u_{t}$ is an i.i.d., mean-zero random error. Then,

$$
\operatorname{Var}\left(q_{t}-q_{t-n}\right)=\frac{2\left(1-b^{n}\right)}{1-b^{2}} \operatorname{Var}\left(u_{t}\right)
$$

For $n=1$ (that is, monthly differences), this variance is indeed larger when $b$ is small, holding the variance of the innovation constant. If prices adjust quickly, the variance of their first differences might actually be larger than for prices that adjust slowly. But, as $n$ gets large, the variance of the $n$ thdifference declines as $b$ declines. That suggests using longer differences to see if our findings with first differences are an artifact produced by rapidly adjusting prices.

In order to examine the importance of this potential explanation of our results, we calculate standard deviations for 24-month differences. As reported in the last column of Table 2, we find the 
same pattern as for the 1-month differences. For the traded goods, the weighted-average standard deviation of $\Delta_{24} p_{j t}^{k}-\Delta_{24} p_{j t}^{m}$ is 8.66 (where $\Delta_{24}$ refers tot he 24-month difference), while it is equal to 5.03 for non-traded goods. The largest deviations still tend to be for the traded goods, and the smallest for the non-traded.

This finding stands on its head the usual approach to examining real exchange rates. Trade theory usually assumes that the law of one price holds for traded goods, but not for non-traded goods. The classification of goods into tradables and non-tradables seems useless at best, and actually perverse since PLOP holds less well for tradables.

The sticky-price explanation for why PLOP holds relatively well across cities within the U.S. contends that the standard deviation of $\Delta p_{j t}^{k}-\Delta p_{j t}^{m}$ is small because neither nominal price changes very much in the short run. Of course, not all goods prices are equally sticky. In parentheses in each column of table 2 are the cross-city averages of the standard deviations of the nominal prices of each good. To be clear, here we are not measuring deviations from the law of one price. We are calculating the volatility of nominal (not relative) prices. The stickier are prices, the lower the nominal volatility.

Some prices are very stable on a month-to-month basis, such as "rent, residential" and "food away from home". The goods and services that are sold in "customer markets" tend to respond less to transitory fluctuations in demand. On the other hand, some of our consumer goods are nearer to "auction market" commodities. The standard deviation of the prices of such goods as "fresh fruits and vegetables", "eggs" and "infants' and toddlers' apparel” is quite high.

The sticky-price story is that PLOP holds more nearly for goods whose prices have a low standard deviation. Hence we should see a strong positive relationship between the standard deviation of $\Delta p_{j t}^{k}-\Delta p_{j t}^{m}$ and the sum of the standard deviations of $\Delta p_{j t}^{k}$ and $\Delta p_{j t}^{m}$. Figure 1 plots this 
relationship. The graph shows that the predictions of the sticky-price explanation for PLOP deviations are strongly supported. The less variable the nominal price, the larger the PLOP deviation.

This pattern also explains why the traded goods tend to have larger PLOP deviations. As Table 2 reports, the average standard deviation of one-month differences of the nominal prices for traded goods is 3.26 , while it is only 1.24 for the non-traded goods. It appears that the "auction market" goods, for which prices are less sticky, are also the most tradable goods. The "customer market" goods, for which prices are more sticky, are non-tradables.

Another way to interpret Figure 1 is to note that

$$
\operatorname{Var}\left(\Delta p_{j t}^{k}-\Delta p_{j t}^{m}\right)=\operatorname{Var}\left(\Delta p_{j t}^{k}\right)+\operatorname{Var}\left(\Delta p_{j t}^{m}\right)-2 \operatorname{Cov}\left(\Delta p_{j t}^{k}, \Delta p_{j t}^{m}\right) .
$$

There are two possible ways the variance of the relative price could be low. One is if the variance of each price is small (and the covariance is small.) Alternatively, even if the variances of each prices is large, if the covariance is also large, the variance of the relative price will be small. Figure 1 shows that the first explanation is the relevant one for our U.S. city prices.

Do transportation costs explain any of the deviations from PLOP? Our finding that traded goods have larger deviations from PLOP than nontraded goods suggest that transportation costs are not the major explanation. We can measure the effects of transportation costs by relying on the methods in Engel and Rogers $(1996,1998)$. The transportation costs for any good ought to be increasing with the distance which the good must be transported. So, PLOP deviations should be greater for more distance pairs of cities. The standard deviation of $\Delta p_{j t}^{k}-\Delta p_{j t}^{m}$ ought to be positively related to the distance between locations $k$ and $m$.

Table 3 reports the results from regressing the standard deviation of $\Delta p_{j t}^{k}-\Delta p_{j t}^{m}$ on the log of the distance between city pairs. Column 1 reports the coefficient (and standard errors) for that regression for each of the 43 goods. The estimated relationship is positive in 30 of the 43 regressions, 
and is significantly greater than zero (at the 5 per cent level) in 24 . The last line of the column (1) in Table 4 reports the results for a regression which pools all of the goods, using weighted OLS and a dummy variable for each good. There, the distance variable has a positive and strongly significant relationship to the standard deviation of $\Delta p_{j t}^{k}-\Delta p_{j t}^{m}$.

In practice, there appears to be "city effects" in the data - PLOP deviations are larger for some cities than for others, even taking distance into account. In the second column of Table 3, we report regressions relating the standard deviation of $\Delta p_{j t}^{k}-\Delta p_{j t}^{m}$ to the log of distance, while including dummy variables for cities. So, for the standard deviation of $\Delta p_{j t}^{k}-\Delta p_{j t}^{m}$, the city $\mathrm{k}$ and city $\mathrm{m}$ dummies would receive a value of one, while all the other dummies would get zeros. The city dummies thus capture those factors that make final goods prices in some cities more variable than in other cities. We do not have data at the city level on enough economic variables to understand why the city dummies matter. Factors contributing to higher volatility in a city might include the absence of formal price controls (such as rent controls), relatively flexible labor markets, and more variability in tax rates.

The relationship between PLOP deviations and distance is about the same as in the regressions without the city dummies. The relationship is positive in 31 of the 43 regressions, and is significantly greater than zero in 14. The pooled regression finds a positive and strongly significant relationship. Moreover, the city dummies as a whole are highly significant, as suggested by the increase in the $R^{2}$ statistics.

These regressions allow only distance to explain deviations from PLOP. In the last column of Table 3, we regress standard deviation of $\Delta p_{j t}^{k}-\Delta p_{j t}^{m}$ on the log of the distance between locations $k$ and $m$, and the sum of the standard deviations of $\Delta p_{j t}^{k}$ and $\Delta p_{j t}^{m}$ (as well as dummy variables for each city.) We find strong evidence that when nominal prices are more volatile, PLOP failures are larger. The 
coefficients on the sum of the standard deviations of $\Delta p_{j t}^{k}$ and $\Delta p_{j t}^{m}$ are positive for 35 of the 43 goods and significant at the 5 percent level for 32. Furthermore, this variable is even more strongly significant in the pooled regression - suggesting that differences in the volatility of the nominal prices of each good helps explain differences in the failure of PLOP across the goods. This regression takes into account the distance between city pairs. So, this can be interpreted as saying that deviations from PLOP for city pairs that are zero miles apart are strongly related to the volatility of nominal prices.

\section{Conclusions}

Our results indicate that deviations from PLOP across U.S. cities can be explained by two factors: distance between locations and the volatility of nominal prices. When we compare the prices of goods across city pairs, the more distant the city pairs the larger the deviations from PLOP. But we also find that goods with a large nominal price variance show large deviations from PLOP, irrespective of the distance between locations.

We attribute the first of these findings to transportation costs. When goods are sold in distant cities, the economic forces that would work to equalize prices are weaker.

The second finding we attribute to the role of sticky nominal prices. We contend that goods sold in customer markets exhibit lower nominal price volatility. There are smaller variations in $\Delta p_{j t}^{k}-\Delta p_{j t}^{m}$ not because there are economic forces working toward enforcing equal prices across locations. Instead, $\Delta p_{j t}^{k}-\Delta p_{j t}^{m}$ is stable simply because there is not much variation in each nominal price. We find, in fact, that deviations from PLOP are actually smaller for non-traded goods than traded goods, which we attribute to greater nominal price stickiness for non-traded goods.

There is a limited amount that one can learn from looking at prices alone. It would be useful to bring in independent evidence on nominal price stickiness (for instance, evidence on the frequency of 
price adjustment across industries), on transportation costs, and on marketing and distribution costs. It is left for future research to bring more evidence to bear on these open questions.

\section{References}

Engel, Charles, 1993, Real exchange rates and relative prices, Journal of Monetary Economics 32, 3550.

Engel, Charles, and John H. Rogers, 1996, How wide is the border?, American Economic Review 86, 1112-1125.

Engel, Charles, and John H. Rogers, 1998, Regional patterns in the law of one price: The roles of geography vs. currencies, in Jeffrey A. Frankel, ed., The Regionalization of the World Economy (Chicago: University of Chicago Press).

Helliwell, John, 1996, Do national borders matter for Quebec's trade?, Canadian Journal of Economics 29, 507-522.

Kravis, Irving B., and Robert E. Lipsey, National price levels and the prices of tradables and nontradables, American Economic Review Papers and Proceedings 78, 474-478.

McCallum, John, 1995, National borders matter: Canada-U.S. regional trade patterns, American Economic Review 85, 615-623.

Parsley, David, and Shang-Jin Wei, 1996, Convergence to the law of one price without trade barriers or currency fluctuations, Quarterly Journal of Economics 111, 1211-1236.

\footnotetext{
1 It would be difficult to disaggregate this component any further - virtually all of it consists of "owners' equivalent rent."

2 The data are from the Bureau of Labor Statistics. The one category of prices for which we could not obtain price data from the BLS was for medical insurance.

${ }^{3}$ We should also mention that relative to Engel and Rogers (1996), our data set for the U.S. in this paper is much more comprehensive. It covers 29 U.S. cities versus 14 in the 1996 study. Our price data in this paper is for 43 categories of goods which make up over $99 \%$ of the C.P.I., while the 1996 paper only disaggregated into 14 categories that account for around $94.6 \%$ of expenditures. On the other hand, the 1996 paper included prices for Canada as well as for the U.S.
} 
</ref_section> 
Figure 1: Law of One Price Deviation vs. Volatility of Nominal Prices

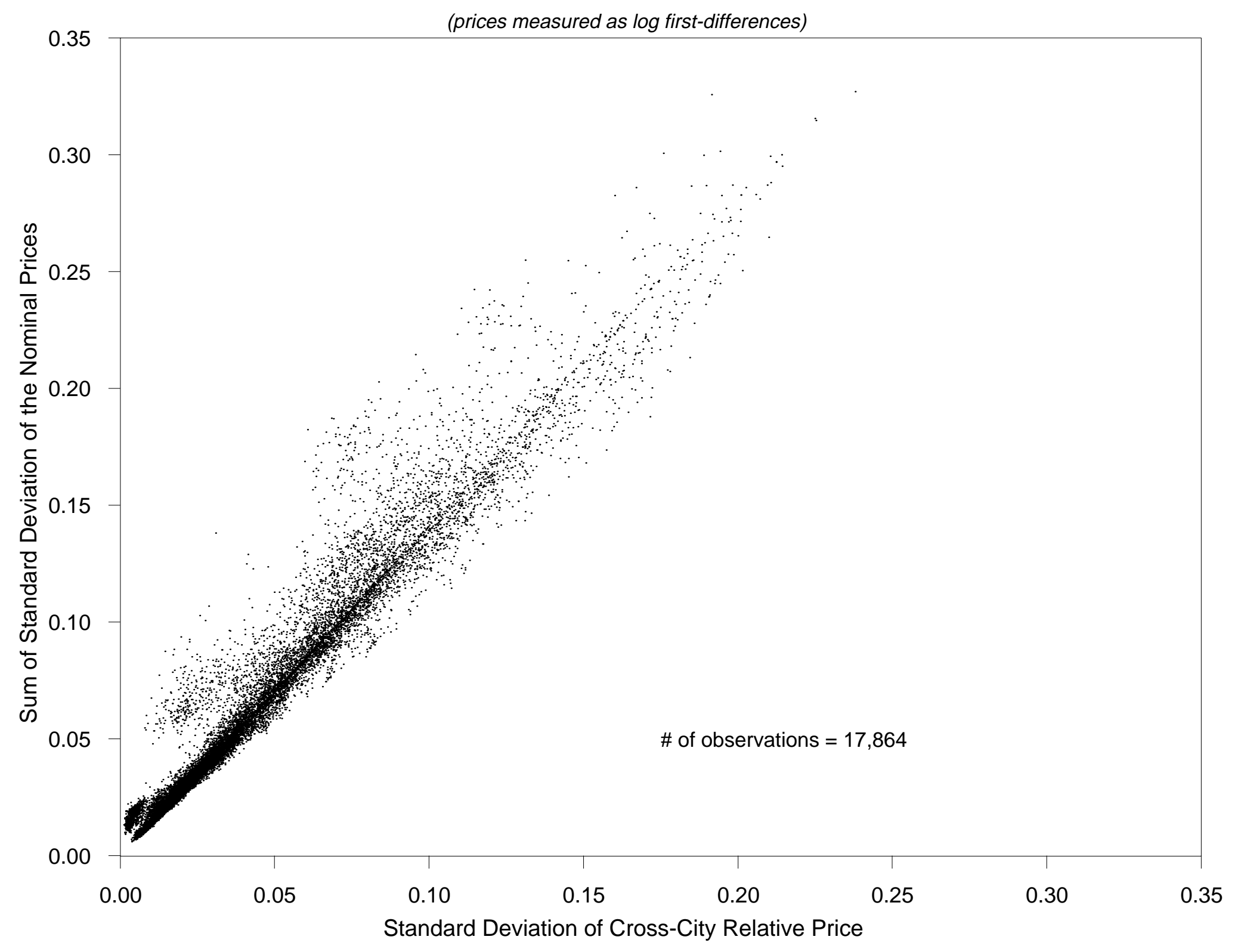


Table 1: Ratio of Inter-City Relative Price Variability to Cross-City L.O.P. Deviation (average ratio, by good)

\begin{tabular}{|c|c|c|}
\hline Good (weight) ${ }^{\mathrm{a}}$ & Std. dev. of 1 st diff. ${ }^{\text {B }}$ & 24-mo. Diff. ${ }^{\mathrm{C}}$ \\
\hline Cereals \& Bakery Products (1.440) & 1.37 & 1.78 \\
\hline Meats (2.057) & 1.31 & 1.87 \\
\hline Poultry $(0.463)$ & 0.84 & 1.11 \\
\hline Fish and Seafood $(0.385)$ & 0.76 & 0.83 \\
\hline Eggs $(0.214)$ & 0.99 & 1.41 \\
\hline Dairy Products (1.296) & 1.53 & 1.95 \\
\hline Fresh Fruits \& Vegetables (1.150) & 0.95 & 1.05 \\
\hline Processed Fruits and Vegetables (0.663) & 1.12 & 1.41 \\
\hline Other Food at Home (2.462) & 1.58 & 2.00 \\
\hline Food Away from Home (6.189) [N] & 3.88 & 2.96 \\
\hline Alcoholic Beverages (1.546) & 1.85 & 1.73 \\
\hline Other renters' costs $(1.916)[\mathrm{N}]$ & 0.97 & 0.96 \\
\hline Homeowners' costs $(19.825)[\mathrm{N}]$ & 2.46 & 1.92 \\
\hline Maintenance \& Repairs $(0.212)[\mathrm{N}]$ & 1.14 & 0.91 \\
\hline Fuels (4.214) & 0.86 & 1.14 \\
\hline Other Utilities \& public services (3.269) [N] & 1.37 & 1.62 \\
\hline Textile Housefurnishings (0.394) & 0.80 & 0.83 \\
\hline Furniture and bedding (1.188) & 0.88 & 0.88 \\
\hline Appliances, incl. electronic equipment (1.105) & 1.23 & 1.18 \\
\hline Other housefurnishings (1.296) & 1.01 & 1.02 \\
\hline Housekeeping supplies (1.202) & 1.29 & 1.23 \\
\hline Housekeeping services $(1.461)[\mathrm{N}]$ & 2.05 & 1.57 \\
\hline Rent, residential (5.955) $[\mathrm{N}]$ & 3.14 & 2.10 \\
\hline Men's and boy's apparel (1.497) & 0.95 & 1.00 \\
\hline Women's and girls' apparel (2.495) & 0.79 & 0.81 \\
\hline Infants' and toddlers' apparel $(0.213)$ & 0.71 & 0.68 \\
\hline Other apparel commodities $(0.545)$ & 0.77 & 0.78 \\
\hline Footwear $(0.823)$ & 0.93 & 0.96 \\
\hline Apparel services $(0.557)[\mathrm{N}]$ & 1.80 & 1.25 \\
\hline New vehicles (5.226) & 2.51 & 2.56 \\
\hline Used cars (1.237) & 6.61 & 2.73 \\
\hline Auto maintenance and repair (1.524) $[\mathrm{N}]$ & 1.91 & 1.49 \\
\hline Other private transportation $(4.532)[\mathrm{N}]$ & 1.91 & 1.56 \\
\hline Public transportation (1.432) & 1.03 & 0.99 \\
\hline Motor Fuel (3.152) & 1.69 & 2.02 \\
\hline Medical Care commodities (1.179) & 1.70 & 1.49 \\
\hline Professional medical services (3.103) $[\mathrm{N}]$ & 2.44 & 1.97 \\
\hline Hospital and related services (1.757) $[\mathrm{N}]$ & 1.61 & 1.49 \\
\hline
\end{tabular}




\begin{tabular}{lll} 
Entertainment commodities (2.079) & 1.72 & 1.60 \\
Entertainment services (2.317) [N] & 1.42 & 1.34 \\
Tobacco and smoking products (1.478) & 1.18 & 1.30 \\
Personal Care (1.217) & 1.47 & 1.28 \\
Personal and educational expenses (3.568) [N] & 2.44 & 1.75 \\
\hline 43-good weighted average & 2.03 & 1.90 \\
Non-traded Goods weight. avg. & 2.42 & 1.56 \\
Traded Goods weighted avg. & 1.54 & 1.52 \\
\hline \hline
\end{tabular}

Notes: The sample period is December 1986 to June 1996. The cities included are: New York, Philadelphia, Chicago, Los Angeles, San Francisco, Boston, Cleveland, Cincinnati, Washington, Baltimore, Sant Louis, Minneapolis, Milwaukee, New Orleans, San Diego, Portland, Buffalo, Dallas, Atlanta, Anchorage, Denver, Detroit, Miami, Kansas City, Houston, Honolulu, Pittsburgh, Tampa, Seattle.

(a) Column 1 lists in parenthesis the good's weight in the overall CPI; U.S. city average, Dec. 1989. The goods classified as non-traded $[\mathrm{N}]$ are: food away from home, other renters' costs, rent residential, homeowners' costs, maintenance and repairs, other utilities and public services, housekeeping services, apparel services, auto maintenance and repairs, other private transportation, professional medical services, hospital and related services, entertainment services, personal and educational expenses.

(b) The mean ratio of relative price volatility within city to the l.o.p. deviation across cities, for each good. The measure of volatility is the standard deviation of the relative price series. Prices are measured as one-month $\log$ differences.

(c) As in (b), except that prices are measured as 24-month log differences. 
Table 2: Average Law of One Price Deviation and the Variability of Individual Goods' Prices

\begin{tabular}{|c|c|c|c|c|}
\hline \multirow{2}{*}{$\begin{array}{l}\text { Good (weight) } \\
\text { Cereals \& Bakery Products (1.440) }\end{array}$} & \multicolumn{2}{|c|}{$\begin{array}{c}\text { Avg. L.O.P. Deviation } \\
\text { (Nominal Price variability.) - } \\
\text { Std dev. of 1st diff. }{ }^{\text {a }} \\
\end{array}$} & \multicolumn{2}{|c|}{$\begin{array}{l}\text { Avg. L.O.P. Deviation } \\
\text { (Nom. Price variab.) - } \\
\text { Std. dev. of 24th diff. } \\
\end{array}$} \\
\hline & 2.90 & $(2.02)$ & 4.91 & $(4.73)$ \\
\hline Meats (2.057) & 3.12 & $(2.23)$ & 5.07 & $(6.34)$ \\
\hline Poultry $(0.463)$ & 7.87 & $(5.60)$ & 11.6 & $(10.2)$ \\
\hline Fish and Seafood $(0.385)$ & 9.64 & $(6.54)$ & 17.4 & $(12.1)$ \\
\hline Eggs $(0.214)$ & 8.93 & $(8.10)$ & 14.3 & $(18.9)$ \\
\hline Dairy Products (1.296) & 2.53 & $(1.84)$ & 4.67 & $(5.60)$ \\
\hline Fresh Fruits \& Vegetables (1.150) & 8.05 & $(6.74)$ & 13.9 & $(12.2)$ \\
\hline Processed Fruits and Vegetables (0.663) & 4.02 & $(2.82)$ & 7.23 & $(7.16)$ \\
\hline Other Food at Home (2.462) & 2.38 & $(1.70)$ & 4.31 & $(3.74)$ \\
\hline Food Away from Home (6.189) [N] & 0.85 & $(0.59)$ & 2.70 & $(2.65)$ \\
\hline Alcoholic Beverages (1.546) & 1.97 & $(1.46)$ & 5.50 & $(5.57)$ \\
\hline Other renters' costs $(1.916)[\mathrm{N}]$ & 6.38 & $(5.02)$ & 13.8 & $(10.7)$ \\
\hline Homeowners' costs $(19.825)[\mathrm{N}]$ & 1.40 & $(0.98)$ & 4.39 & $(3.26)$ \\
\hline Maintenance \& Repairs $(0.212)[\mathrm{N}]$ & 3.91 & $(2.66)$ & 13.2 & $(9.00)$ \\
\hline Fuels (4.214) & 7.29 & $(5.07)$ & 9.41 & $(6.88)$ \\
\hline Other Utilities \& public services (3.269) $[\mathrm{N}]$ & 3.06 & $(1.99)$ & 5.70 & $(4.15)$ \\
\hline Textile Housefurnishings (0.394) & 8.86 & $(6.19)$ & 17.8 & $(12.3)$ \\
\hline Furniture and bedding (1.188) & 6.58 & $(4.53)$ & 15.8 & $(10.8)$ \\
\hline Appliances, incl. electronic equipment (1.105) & 3.43 & $(2.39)$ & 8.71 & $(6.03)$ \\
\hline Other housefurnishings (1.296) & 4.89 & $(3.42)$ & 10.8 & $(7.51)$ \\
\hline Housekeeping supplies (1.202) & 3.20 & $(2.24)$ & 8.17 & $(6.26)$ \\
\hline Housekeeping services (1.461) [N] & 1.84 & $(1.32)$ & 6.04 & $(4.51)$ \\
\hline Rent, residential (5.955) [N] & 1.07 & $(0.75)$ & 4.05 & $(2.98)$ \\
\hline Men's and boy's apparel (1.497) & 5.77 & $(4.22)$ & 11.2 & $(8.29)$ \\
\hline Women's and girls' apparel (2.495) & 11.3 & $(8.33)$ & 19.1 & $(13.8)$ \\
\hline Infants' and toddlers' apparel (0.213) & 13.3 & $(9.06)$ & 32.5 & $(22.0)$ \\
\hline Other apparel commodities $(0.545)$ & 9.33 & $(6.40)$ & 20.1 & $(14.1)$ \\
\hline Footwear (0.823) & 5.97 & $(4.30)$ & 12.6 & $(9.05)$ \\
\hline Apparel services $(0.557)[\mathrm{N}]$ & 2.05 & $(1.39)$ & 7.75 & $(5.38)$ \\
\hline New vehicles (5.226) & 1.38 & $(1.08)$ & 3.41 & $(2.54)$ \\
\hline Used cars (1.237) & 0.53 & $(1.00)$ & 4.82 & $(8.14)$ \\
\hline Auto maintenance and repair $(1.524)[\mathrm{N}]$ & 1.90 & $(1.30)$ & 6.05 & $(4.31)$ \\
\hline Other private transportation $(4.532)[\mathrm{N}]$ & 1.88 & $(1.37)$ & 5.88 & $(4.62)$ \\
\hline Public transportation (1.432) & 4.97 & $(3.74)$ & 13.7 & $(10.9)$ \\
\hline Motor Fuel (3.152) & 2.98 & $(3.48)$ & 6.44 & $(10.8)$ \\
\hline Medical Care commodities (1.179) & 2.16 & $(1.50)$ & 6.38 & $(6.11)$ \\
\hline Professional medical services (3.103) [N] & 1.40 & $(0.98)$ & 4.27 & $(3.32)$ \\
\hline
\end{tabular}




\begin{tabular}{lllll} 
Hospital and related services (1.757) [N] & 2.32 & $(1.65)$ & 6.43 & $(5.84)$ \\
Entertainment commodities (2.079) & 2.13 & $(1.48)$ & 5.54 & $(4.18)$ \\
Entertainment services $(2.317)[\mathrm{N}]$ & 2.74 & $(1.89)$ & 6.93 & $(5.09)$ \\
Tobacco and smoking products (1.478) & 3.83 & $(2.88)$ & 11.1 & $(12.7)$ \\
Personal Care (1.217) & 2.63 & $(1.83)$ & 7.30 & $(5.39)$ \\
Personal and educational expenses (3.568) [N] & 1.44 & $(1.19)$ & 4.80 & $(3.61)$ \\
\hline 43-good weighted average & 2.87 & $(2.12)$ & 6.61 & $(5.36)$ \\
Non-traded Goods weight. avg. & 1.74 & $(1.24)$ & 5.03 & $(3.86)$ \\
Traded Goods weighted avg. & 4.35 & $(3.26)$ & 8.66 & $(7.53)$ \\
\hline \hline
\end{tabular}

(a) The mean law of one price deviation across cities. The 1.o.p. deviation is measured as the standard deviation of the good's relative price (x 100). In parenthesis is the average standard deviation of the price of the good itself across all 29 cities (x 100). Note that the latter is not a relative price. Prices are measured as one-month log differences.

(b) As in (a), except that prices are measured as 24-month log differences. 
Table 3: Explaining Law of One Price Deviations

Specification: 1 2 3

\begin{tabular}{|c|c|c|c|c|c|c|c|}
\hline Good & $\begin{array}{c}\text { Log } \\
\text { Distance }\end{array}$ & Adj. R2 & $\begin{array}{c}\text { Log } \\
\text { Distance }\end{array}$ & Adj. R2 & $\begin{array}{c}\text { Log } \\
\text { Distance }\end{array}$ & $\begin{array}{c}\text { Sum of } \\
\text { Std. } \\
\text { Dev. }\end{array}$ & Adj. R2 \\
\hline Cereals \& Bakery Products & $\begin{array}{l}-6.40 \\
(4.86)\end{array}$ & .00 & $\begin{array}{l}-0.51 \\
(1.51)\end{array}$ & .94 & $\begin{array}{l}-0.51 \\
(1.51)\end{array}$ & $\begin{array}{c}0.70 \\
(0.03)\end{array}$ & .94 \\
\hline Meats & $\begin{array}{c}18.8 \\
(3.65)\end{array}$ & .05 & $\begin{array}{l}-0.93 \\
(1.29)\end{array}$ & .93 & $\begin{array}{l}-0.93 \\
(1.29)\end{array}$ & $\begin{array}{c}0.72 \\
(0.02)\end{array}$ & .93 \\
\hline Poultry & $\begin{array}{l}-2.15 \\
(8.69)\end{array}$ & .00 & $\begin{array}{l}-4.40 \\
(3.27)\end{array}$ & .91 & $\begin{array}{l}-4.40 \\
(3.27)\end{array}$ & $\begin{array}{c}0.74 \\
(0.02)\end{array}$ & .91 \\
\hline Fish and Seafood & $\begin{array}{l}149.0 \\
(20.1)\end{array}$ & .12 & $\begin{array}{c}9.76 \\
(4.29)\end{array}$ & .97 & $\begin{array}{c}9.76 \\
(4.29)\end{array}$ & $\begin{array}{c}0.66 \\
(0.03)\end{array}$ & .97 \\
\hline Eggs & $\begin{array}{c}13.5 \\
(12.9)\end{array}$ & .00 & $\begin{array}{c}23.4 \\
(6.37)\end{array}$ & .86 & $\begin{array}{c}23.4 \\
(6.37)\end{array}$ & $\begin{array}{c}0.48 \\
(0.03)\end{array}$ & .86 \\
\hline Dairy Products & $\begin{array}{c}23.9 \\
(3.55)\end{array}$ & .10 & $\begin{array}{c}4.45 \\
(1.18)\end{array}$ & .95 & $\begin{array}{c}4.58 \\
(1.18)\end{array}$ & $\begin{array}{c}25.8 \\
(3.84)\end{array}$ & .95 \\
\hline Fresh Fruits \& Vegetables & $\begin{array}{c}73.6 \\
(8.17)\end{array}$ & .16 & $\begin{array}{c}21.1 \\
(3.76)\end{array}$ & .92 & $\begin{array}{c}21.1 \\
(3.76)\end{array}$ & $\begin{array}{c}0.49 \\
(0.02)\end{array}$ & .92 \\
\hline Processed Fruits and Vegetables & $\begin{array}{c}19.7 \\
(6.71)\end{array}$ & .01 & $\begin{array}{c}-2.31 \\
(1.86)\end{array}$ & .97 & $\begin{array}{l}-2.31 \\
(1.86)\end{array}$ & $\begin{array}{c}0.74 \\
(0.02)\end{array}$ & .97 \\
\hline Other Food at Home & $\begin{array}{c}13.9 \\
(3.04)\end{array}$ & .04 & $\begin{array}{c}2.85 \\
(1.13)\end{array}$ & .95 & $\begin{array}{c}2.96 \\
(1.13)\end{array}$ & $\begin{array}{l}-23.9 \\
(3.21)\end{array}$ & .95 \\
\hline Food Away from Home & $\begin{array}{c}4.32 \\
(1.14)\end{array}$ & .03 & $\begin{array}{c}0.29 \\
(0.68)\end{array}$ & .84 & $\begin{array}{c}0.30 \\
(0.68)\end{array}$ & $\begin{array}{l}-0.56 \\
(1.67)\end{array}$ & .84 \\
\hline Alcoholic Beverages & $\begin{array}{c}20.1 \\
(2.69)\end{array}$ & .11 & $\begin{array}{c}0.84 \\
(1.33)\end{array}$ & .85 & $\begin{array}{c}0.84 \\
(1.33)\end{array}$ & $\begin{array}{c}0.65 \\
(0.04)\end{array}$ & .85 \\
\hline Other renters' costs & $\begin{array}{c}13.0 \\
(8.50)\end{array}$ & .00 & $\begin{array}{c}23.4 \\
(4.79)\end{array}$ & .90 & $\begin{array}{c}23.4 \\
(4.79)\end{array}$ & $\begin{array}{c}0.62 \\
(0.03)\end{array}$ & .90 \\
\hline Homeowners' costs & $\begin{array}{c}11.8 \\
(1.61)\end{array}$ & .13 & $\begin{array}{c}0.98 \\
(0.61)\end{array}$ & .92 & $\begin{array}{c}0.91 \\
(0.60)\end{array}$ & $\begin{array}{l}-2.61 \\
(1.37)\end{array}$ & .92 \\
\hline Maintenance \& Repairs & $\begin{array}{c}20.3 \\
(7.04)\end{array}$ & .01 & $\begin{array}{c}1.78 \\
(2.20)\end{array}$ & .97 & $\begin{array}{c}1.78 \\
(2.20)\end{array}$ & $\begin{array}{c}0.69 \\
(0.05)\end{array}$ & .97 \\
\hline Fuels & $\begin{array}{l}-1.31 \\
(16.2)\end{array}$ & .00 & $\begin{array}{c}45.8 \\
(7.30)\end{array}$ & .87 & $\begin{array}{c}45.8 \\
(7.30)\end{array}$ & $\begin{array}{c}0.63 \\
(0.03)\end{array}$ & .87 \\
\hline Other Utilities \& public services & $\begin{array}{l}-29.7 \\
(12.0)\end{array}$ & .01 & $\begin{array}{c}11.6 \\
(2.99)\end{array}$ & .98 & $\begin{array}{c}11.8 \\
(3.02)\end{array}$ & $\begin{array}{c}26.0 \\
(4.74)\end{array}$ & .98 \\
\hline Textile Housefurnishings & $\begin{array}{c}15.4 \\
(10.4)\end{array}$ & .00 & $\begin{array}{c}2.63 \\
(2.83)\end{array}$ & .95 & $\begin{array}{c}2.63 \\
(2.83)\end{array}$ & $\begin{array}{c}0.66 \\
(0.02)\end{array}$ & .95 \\
\hline Furniture and bedding & $\begin{array}{c}59.8 \\
(8.19)\end{array}$ & .13 & $\begin{array}{c}6.66 \\
(2.99)\end{array}$ & .93 & $\begin{array}{c}6.66 \\
(2.99)\end{array}$ & $\begin{array}{c}0.70 \\
(0.02)\end{array}$ & .93 \\
\hline $\begin{array}{l}\text { Appliances, including electronic } \\
\text { equipment }\end{array}$ & $\begin{array}{l}-4.00 \\
(4.06)\end{array}$ & .00 & $\begin{array}{l}-1.97 \\
(1.20)\end{array}$ & .95 & $\begin{array}{l}-1.97 \\
(1.20)\end{array}$ & $\begin{array}{c}0.76 \\
(0.03)\end{array}$ & .95 \\
\hline Other housefurnishings & $\begin{array}{c}20.6 \\
(4.88)\end{array}$ & .03 & $\begin{array}{c}4.64 \\
(1.86)\end{array}$ & .94 & $\begin{array}{c}4.64 \\
(1.86)\end{array}$ & $\begin{array}{c}0.67 \\
(0.03)\end{array}$ & .94 \\
\hline Housekeeping supplies & $\begin{array}{l}-0.84 \\
(2.63)\end{array}$ & .00 & $\begin{array}{c}1.31 \\
(1.10)\end{array}$ & .88 & $\begin{array}{c}1.31 \\
(1.10)\end{array}$ & $\begin{array}{c}0.68 \\
(0.03)\end{array}$ & .88 \\
\hline Housekeeping services & $\begin{array}{c}34.7 \\
(5.94)\end{array}$ & .09 & $\begin{array}{c}1.98 \\
(1.14)\end{array}$ & .98 & $\begin{array}{c}1.99 \\
(1.13)\end{array}$ & $\begin{array}{c}5.10 \\
(3.55)\end{array}$ & .98 \\
\hline Rent, residential & $\begin{array}{l}-1.05 \\
(0.67)\end{array}$ & .00 & $\begin{array}{c}0.43 \\
(0.34)\end{array}$ & .84 & $\begin{array}{c}0.47 \\
(0.33)\end{array}$ & $\begin{array}{c}1.57 \\
(0.79)\end{array}$ & .85 \\
\hline
\end{tabular}




\begin{tabular}{|c|c|c|c|c|c|c|c|}
\hline Men's and boy's apparel & $\begin{array}{l}-7.38 \\
(7.04)\end{array}$ & .00 & $\begin{array}{l}-0.26 \\
(3.37)\end{array}$ & .90 & $\begin{array}{l}-0.26 \\
(3.74)\end{array}$ & $\begin{array}{c}0.71 \\
(0.02)\end{array}$ & .90 \\
\hline Women's and girls' apparel & $\begin{array}{l}-37.1 \\
(18.6)\end{array}$ & .01 & $\begin{array}{c}5.05 \\
(9.84)\end{array}$ & .90 & $\begin{array}{c}5.05 \\
(9.84)\end{array}$ & $\begin{array}{c}0.68 \\
(0.07)\end{array}$ & .90 \\
\hline Infants' and toddlers' apparel & $\begin{array}{c}-104.4 \\
(24.7)\end{array}$ & .06 & $\begin{array}{l}-6.72 \\
(6.43)\end{array}$ & .94 & $\begin{array}{l}-6.72 \\
(6.43)\end{array}$ & $\begin{array}{c}0.75 \\
(0.02)\end{array}$ & .94 \\
\hline Other apparel commodities & $\begin{array}{c}62.3 \\
(15.4)\end{array}$ & .03 & $\begin{array}{c}7.41 \\
(4.60)\end{array}$ & .96 & $\begin{array}{c}7.41 \\
(4.60)\end{array}$ & $\begin{array}{c}0.66 \\
(0.03)\end{array}$ & .96 \\
\hline Footwear & $\begin{array}{l}-23.1 \\
(5.31)\end{array}$ & .04 & $\begin{array}{c}0.20 \\
(2.26)\end{array}$ & .90 & $\begin{array}{c}0.20 \\
(2.26)\end{array}$ & $\begin{array}{c}0.73 \\
(0.01)\end{array}$ & .90 \\
\hline Apparel services & $\begin{array}{c}8.26 \\
(4.11)\end{array}$ & .00 & $\begin{array}{c}1.25 \\
(1.03)\end{array}$ & .97 & $\begin{array}{c}1.13 \\
(1.03)\end{array}$ & $\begin{array}{c}6.12 \\
(4.18)\end{array}$ & .97 \\
\hline New vehicles & $\begin{array}{c}7.04 \\
(1.86)\end{array}$ & .03 & $\begin{array}{l}-1.31 \\
(1.46)\end{array}$ & .64 & $\begin{array}{l}-1.37 \\
(1.46)\end{array}$ & $\begin{array}{l}-3.23 \\
(3.79)\end{array}$ & .64 \\
\hline Used cars & $\begin{array}{c}1.32 \\
(0.69)\end{array}$ & .01 & $\begin{array}{c}0.10 \\
(0.23)\end{array}$ & .79 & $\begin{array}{c}0.06 \\
(0.44)\end{array}$ & $\begin{array}{l}-1.64 \\
(1.01)\end{array}$ & .79 \\
\hline Auto maintenance and repair & $\begin{array}{c}18.9 \\
(2.87)\end{array}$ & .09 & $\begin{array}{l}-0.05 \\
(0.92)\end{array}$ & .96 & $\begin{array}{l}-0.18 \\
(0.92)\end{array}$ & $\begin{array}{l}-7.94 \\
(2.81)\end{array}$ & .96 \\
\hline Other private transportation & $\begin{array}{c}5.22 \\
(2.25)\end{array}$ & .01 & $\begin{array}{c}1.28 \\
(1.26)\end{array}$ & .88 & $\begin{array}{c}1.32 \\
(1.26)\end{array}$ & $\begin{array}{c}8.38 \\
(3.02)\end{array}$ & .88 \\
\hline Public transportation & $\begin{array}{c}27.8 \\
(5.88)\end{array}$ & .05 & $\begin{array}{c}3.94 \\
(4.18)\end{array}$ & .74 & $\begin{array}{c}3.94 \\
(4.18)\end{array}$ & $\begin{array}{c}0.60 \\
(0.04)\end{array}$ & .74 \\
\hline Motor Fuel & $\begin{array}{c}21.0 \\
(5.48)\end{array}$ & .03 & $\begin{array}{c}37.8 \\
(4.01)\end{array}$ & .77 & $\begin{array}{c}37.8 \\
(4.01)\end{array}$ & $\begin{array}{c}0.22 \\
(0.03)\end{array}$ & .77 \\
\hline Medical Care commodities & $\begin{array}{c}3.28 \\
(2.97)\end{array}$ & .00 & $\begin{array}{c}0.39 \\
(1.02)\end{array}$ & .92 & $\begin{array}{c}0.42 \\
(1.02)\end{array}$ & $\begin{array}{c}3.58 \\
(8.97)\end{array}$ & .92 \\
\hline Professional medical services & $\begin{array}{c}0.17 \\
(1.88)\end{array}$ & .00 & $\begin{array}{l}-0.73 \\
(1.05)\end{array}$ & .81 & $\begin{array}{l}-0.74 \\
(1.05)\end{array}$ & $\begin{array}{l}-0.13 \\
(2.30)\end{array}$ & .81 \\
\hline Hospital and related services & $\begin{array}{c}5.77 \\
(3.16)\end{array}$ & .01 & $\begin{array}{l}-1.32 \\
(1.99)\end{array}$ & .79 & $\begin{array}{l}-1.27 \\
(1.99)\end{array}$ & $\begin{array}{c}13.5 \\
(4.50)\end{array}$ & .79 \\
\hline Entertainment commodities & $\begin{array}{c}11.6 \\
(2.93)\end{array}$ & .03 & $\begin{array}{l}-0.05 \\
(0.84)\end{array}$ & .96 & $\begin{array}{l}-0.05 \\
(0.84)\end{array}$ & $\begin{array}{l}-2.95 \\
(2.63)\end{array}$ & .96 \\
\hline Entertainment services & $\begin{array}{c}-9.74 \\
(4.73)\end{array}$ & .01 & $\begin{array}{c}2.02 \\
(1.11)\end{array}$ & .97 & $\begin{array}{c}2.02 \\
(1.11)\end{array}$ & $\begin{array}{c}0.67 \\
(0.03)\end{array}$ & .97 \\
\hline Tobacco and smoking products & $\begin{array}{l}-1.61 \\
(5.35)\end{array}$ & .00 & $\begin{array}{c}6.60 \\
(2.69)\end{array}$ & .91 & $\begin{array}{c}6.60 \\
(2.69)\end{array}$ & $\begin{array}{c}0.66 \\
(0.03)\end{array}$ & .91 \\
\hline Personal care & $\begin{array}{c}6.63 \\
(3.12)\end{array}$ & .01 & $\begin{array}{c}0.57 \\
(1.09)\end{array}$ & .94 & $\begin{array}{c}0.57 \\
(1.09)\end{array}$ & $\begin{array}{c}0.70 \\
(0.03)\end{array}$ & .94 \\
\hline $\begin{array}{l}\text { Personal and educational } \\
\text { expenses }\end{array}$ & $\begin{array}{c}1.95 \\
(1.58)\end{array}$ & .00 & $\begin{array}{c}2.20 \\
(0.92)\end{array}$ & .82 & $\begin{array}{c}2.29 \\
(0.92)\end{array}$ & $\begin{array}{c}7.23 \\
(2.71)\end{array}$ & .82 \\
\hline $\begin{array}{l}\text { Goods 1-43 } \\
\text { Pooled, weighted (a) }\end{array}$ & $\begin{array}{c}8.51 \\
(1.15)\end{array}$ & .84 & $\begin{array}{c}3.05 \\
(1.18)\end{array}$ & .85 & $\begin{array}{c}3.07 \\
(0.58)\end{array}$ & $\begin{array}{c}0.70 \\
(.008)\end{array}$ & .97 \\
\hline
\end{tabular}

Notes: Specification 1also includes a constant, while specification 2 contains a dummy for each of the 29 individual cities, in addition to log distance. In specification 3, "Sum of std. dev." equals the sum of the standard deviations of the nominal price for the two cities in the pair. Heteroscedasticity-consistent standard errors [White (1980)] are reported in parenthesis. Coefficients and standard errors on distance are multiplied by $10^{4}$. The dependent variable is the standard deviation of the one-month difference in the relative price. Standard deviations are computed over the sample period $12 / 86$ to $6 / 96$. There are 1274 observations.

(a) Individual goods dummies are also included in the pooled regressions. 